\title{
Growth and Calcification of the Cyanobacterium Homoeothrix crustacea
}

\author{
By ALLAN PENTECOST \\ Biosphere Sciences Division, King's College, Campden Hill Road, London W8 7AH, UK
}

(Received 23 February 1988; revised 17 May 1988)

\begin{abstract}
The annual radial growth rate of Homoeothrix crustacea colonies measured in situ was $1 \cdot 25 \pm 0 \cdot 3$ $\mathrm{mm}$ (mean $\pm 95 \%$ confidence limits), with maximal growth in early summer and minimal growth in winter. Two types of calcification were observed. In winter, the filaments were encrusted with small anhedral calcite crystals which occupied about $15 \%$ of the water-saturated volume of the colony. In summer, a dense (39-56 vol. \%) subsurface layer of calcite was deposited, consisting of larger crystals enclosing filaments of Homoeothrix, whilst the upper 60$100 \mu \mathrm{m}$ was essentially free of encrustation. The streamwaters in which the Homoeothrix was growing were permanently supersaturated with respect to calcite. The results are compared with the growth rates and mineralization processes found in other cyanobacteria.
\end{abstract}

\section{INTRODUCTION}

A small number of cyanobacteria are remarkable for their facility to bind or precipitate calcium carbonate on to their sheaths, thereby forming laminate incrustations which are readily preserved as fossils of considerable geological importance (Pentecost \& Riding, 1986). Today, calcified cyanobacteria are frequently found in freshwater environments supersaturated with respect to calcite. Precisely how calcium carbonate is precipitated onto the sheaths of these microbes is uncertain but several proposals have been made (Pentecost, 1988b). Few cyanobacteria lend themselves to detailed studies of growth and calcification in vivo over prolonged periods. They include Rivularia haematites, the 'semiglobosa' form of Schizothrix calcicola, and Homoeothrix crustacea. The growth of Rivularia has already been investigated (Pentecost, 1987) but there is little information on other species. Homoeothrix often forms hemispherical stromatolitic cushions up to $5 \mathrm{~mm}$ in diameter, and previous studies suggest that Homoeothrix calcification differs from that of other cyanobacteria (Pentecost, 1988a). $\mathrm{H}$. crustacea is widely distributed in calcareous waters and the growth dynamics of this species have not been investigated. In this paper, measurements of growth and calcification rates of a Homoeothrix species are presented for the first time, together with information on streamwater geochemistry.

\section{METHODS}

Growth measurements. Observations were made in Waterfall Beck near Arncliffe, North Yorkshire, UK, at a site $150 \mathrm{~m}$ from its confluence with Cowside Beck (National Grid reference 34/908698), altitude $320 \mathrm{~m}$.

Isolated hemispherical colonies of $\boldsymbol{H}$. crustacea Woronichin were measured moist under a binocular microscope fitted with an eyepiece graticule as previously described (Pentecost, 1987). Initial studies showed that growth rate was independent of colony diameter in the size range $1-2.5 \mathrm{~mm}(P<0.05)$. A minimum of 30 colonies in this size range were measured at regular intervals over a period of one year during 1987.

Calcification. Colonies were air-dried, impregnated with Araldite resin, and $15 \mu \mathrm{m}$ sections prepared for petrological examination. Other colonies were decalcified using $5 \%(w / v)$ EDTA pH 8 , hand-sectioned and examined by light microscopy. For electron microscopy, colonies were dehydrated in ethanol series, critical-point dried with $\mathrm{CO}_{2}$, coated with $\mathrm{Au} / \mathrm{Pd}$ and examined in a Philips 501B scanning electron microscope. 
To obtain the $\mathrm{CaCO}_{3}$ content, colonies were carefully removed, dried at $105^{\circ} \mathrm{C}$ to constant weight, weighed on a five-figure balance then transferred to a small flask from which most of the air was removed with a hand-operated vacuum pump. The colonies were soaked in the flask with air-free, $\mathrm{CaCO}_{3}$-saturated water for 15 min, rapidly blotted and reweighed. Colonies were then decalcified with $0 \cdot 1 \mathrm{M}-\mathrm{HCl}$, washed twice, dried at $105^{\circ} \mathrm{C}$ and weighed. Finally, the residue was ignited in a crucible at $500^{\circ} \mathrm{C}$ and reweighed, allowing the $\mathrm{CaCO}_{3}$ content, organic matter and residue to be determined as a fraction of the wet weight. The experimental error for the $\mathrm{CaCO}_{3}$ content was $\pm 0.9 \%$. Some colonies were dissected to determine the variation of calcification over time.

Water chemistry. Duplicate water samples were collected at the sites and water and air temperature recorded with a thermistor. Samples were returned to a nearby laboratory and analysed for calcium by complexometric titration, and for total $\mathrm{CO}_{2}$ using Gran plots (Mackereth et al., 1978). pH was determined with a calibrated Corning 120 glass electrode at the temperature of collection and the calcite saturation obtained from the analytical concentrations of calcium, total $\mathrm{CO}_{2}$ and $\mathrm{pH}$ using a BASIC computer program incorporating the most recently available equilibrium constants for the freshwater carbonate system. Details of the methodology are given by Truesdell \& Jones (1978). The saturometric method of Stenner (1969) was also used for comparison.

Stream discharge and current speed were estimated over an even cross-section of the beck using an Ott flow-rate meter; a small correction for turbulent flow was included (Morisawa, 1968).

Mean weekly air temperatures were obtained from Malham Tarn meteorological station, situated $3 \mathrm{kw} \mathrm{SW}$ at $380 \mathrm{~m}$ altitude. A small correction was made for altitude using an adiabatic lapse rate of $8^{\circ} \mathrm{C} \mathrm{km}^{-1}$, enabling water temperatures to be estimated at the site. Since in situ air and water temperature were significantly correlated ( $r=+0.882, P<0.01$ ), stream temperature could be predicted throughout the year using a linear regression equation (Pentecost, 1987), viz. $Y=0.628 X+3.057$, where $Y$ is streamwater temperature and $X$ is corrected air temperature $\left({ }^{\circ} \mathrm{C}\right)$.

\section{RESULTS AND DISCUSSION}

Species of Homoeothrix have been reported from many countries and they are widely distributed in calcareous waters (Starmach, 1966a; Kawecka, 1971; Marker, 1976; Sinclair \& Whitton, 1977; Pentecost, 1988a). At least four freshwater species have been observed encrusted with calcium carbonate: $H$. gracilis (Hansg.) Komárek \& Kovačik, H. borneti (Sauv.) Babille, $H$. poljanskii Muzafurov and $H$. crustacea. These species, along with several uncalcified forms, have been ciescribed by Geitler (1932), Starmach (1966b), Komárek \& Kann (1973) and Komárek \& Kovačik (1987), although the characters used to delimit the species (sheath colour, trichome dimensions) are open to doubt considering their known variability in other cyanobacteria. None of these species exactly matched the material studied here, which had exceptionally narrow trichomes, but the organism most closely resembled descriptions of $H$. crustacea. Another cyanobacterium, Schizothrix calcicola f. semiglobosa, can be confused with Homoeothrix; this organism was present in the stream but was normally confined to deposits of tufa. The trichomes of the Waterfall Beck Homoeothrix measured 0.4-1.2 $\mu \mathrm{m}$ in diameter and were found normally in the apical portions of the sheaths. The sheaths were 3-6 $\mu \mathrm{m}$ in diameter, hyaline or pigmented and often fibrous and distally frayed. They exhibited strong formbirefringence under the polarizing microscope. The organism formed hemispherical colonies up to $4 \mathrm{~mm}$ wide which sometimes coalesced to form a continuous crust. Within colonies, most of the trichomes were found at or near the surface, in a layer approximately $200 \mu \mathrm{m}$ thick. During winter, the colony surface was colonized by diatoms which became intermixed with the trichomes. This layer was superficial and did not add significantly to the colony diameter. In older colonies, the innermost areas became colonized by two other cyanobacteria, Phormidium cf. incrustatum and Schizothrix calcicola.

Colonies were firmly attached to rocks and stones in the stream and were never observed exposed to the air. They occurred most abundantly in fully exposed areas subject to flow rates exceeding $0.5 \mathrm{~m} \mathrm{~s}^{-1}$. Homoeothrix was only present in parts of the stream where there was calcite precipitation, and it was sometimes associated with Phormidium incrustatum and the green alga Gongrosira incrustans. A tube-dwelling caddis, Tinodes, was frequently observed among the colonies and sometimes destroyed their inner parts (Fig. 1).

Radial growth rates of colonies were variable, even for those colonizing the same stone. The mean growth rate peaked during early summer when water temperature and light intensity were increasing (Fig. 2). The confidence limits attached to this mean overlap with those obtained in 


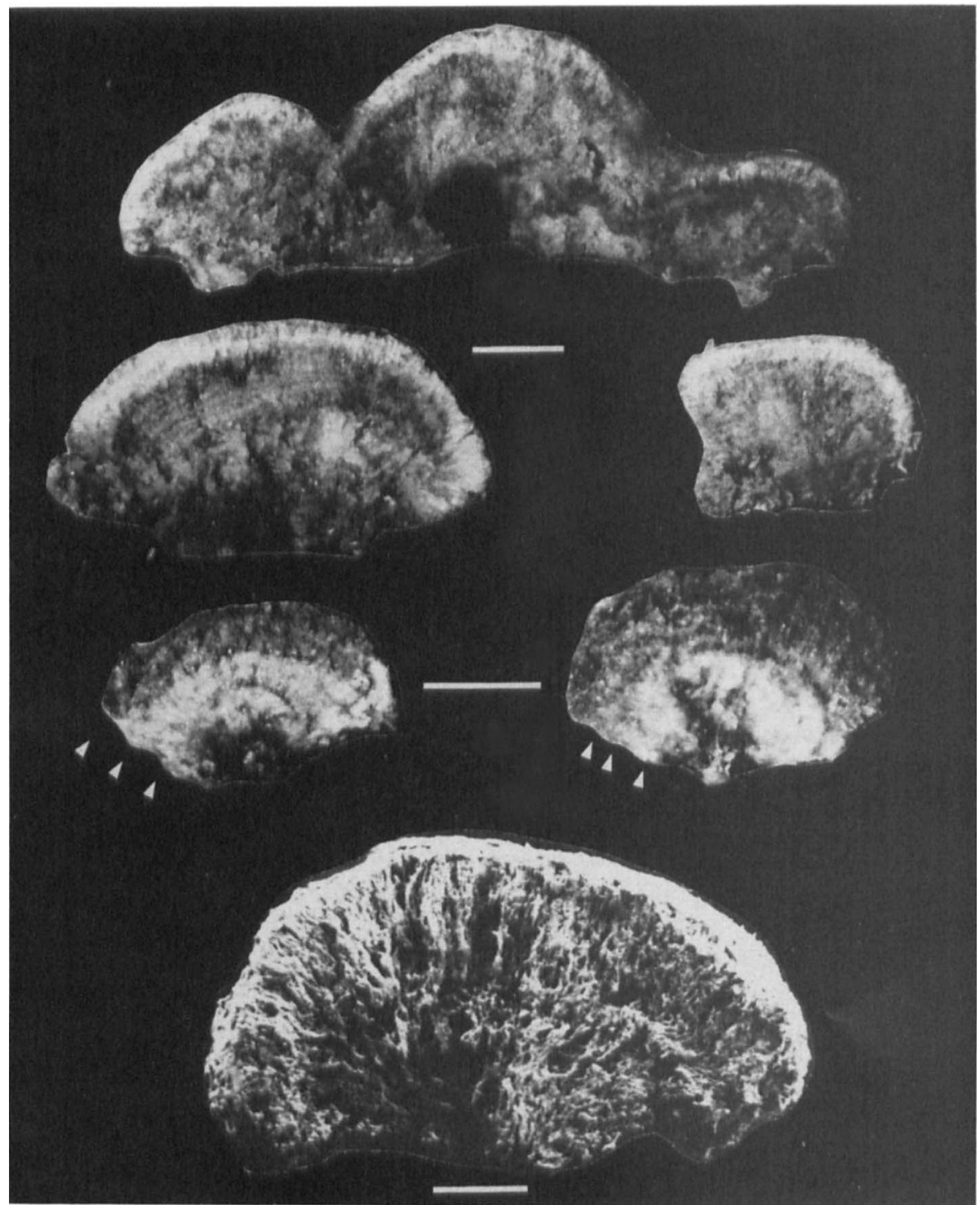

Fig. 1. Sections through colonies of Homoeothrix from Waterfall Beck. Top row: three coalesced colonies, the centre colony bored by Tinodes, 14 August 87 . Note surface calcification. Second row : two further colonies collected on 14 August 87 showing surface calcified layer $0 \cdot 2-0.4 \mathrm{~mm}$ thick and part of a lower pale zone formed in the previous summer. The winter layers have a series of narrow calcified bands. Bar, $10 \mathrm{~mm}$. Third row: measured colonies removed on 21 December 87, showing a dark surface layer and a lower pale summer zone. Arrows mark colony size; from top to bottom the dates are 17 October, 14 August and 19 June 1987. Bar, $10 \mathrm{~mm}$. Fourth row: scanning electron micrograph of a section through a colony collected on 19 June 87, showing the radiating filamentous structure. Criticalpoint-dried material. Bar, $5 \mathrm{~mm}$.

midsummer and autumn but the radial growth rate was significantly lower during winter. The mean radial growth rate ranged from 2.02 to $4.9 \mu \mathrm{m} \mathrm{d}^{-1}$, giving an annual radial growth of 1.25 $\mathrm{mm}$ (Table 1). Despite the high summer growth, the correlation obtained between growth rates and stream water temperature was not very significant $(r=+0.578, P<0.25)$.

This low correlation contrasted with the significant results found in an associated cyanobacterium, Rivularia haematites (Pentecost, 1987). The annual radial growth of 


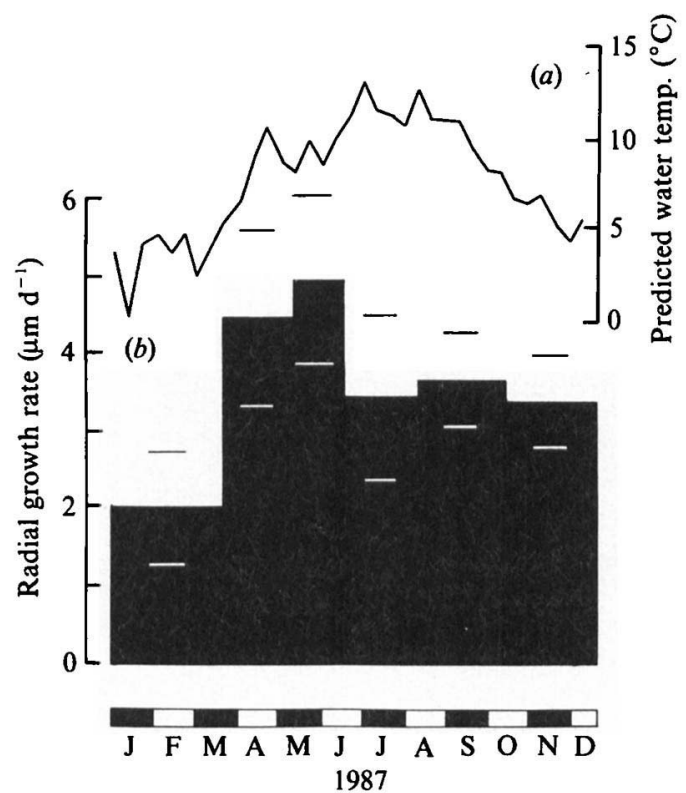

Fig. 2. (a) Predicted $10 \mathrm{~d}$ mean water temperature of Waterfall Beck, 1987. (b) Radial growth rate of Homoeothrix over a one-year period; $95 \%$ confidence limits to the mean are indicated by horizontal lines.

Table 1. Water chemistry (a), Homoeothrix growth rate (b) and calcification (c): means and ranges

(a) Water temp. $\left({ }^{\circ} \mathrm{C}\right)$

Discharge* $^{*}\left(\mathrm{l} \mathrm{s}^{-1}\right)$

$\mathrm{pH}^{*}$

Total $\mathrm{CO}_{2}^{*}(\mathrm{mM})$

Calcium* ${ }^{*}(\mathrm{mM})$

(b) Homoeothrix radial growth

rate \pm confidence limits $\left(\mu \mathrm{m} \mathrm{d}^{-1}\right)$

$\left(\mathrm{mm}\right.$ year $\left.^{-1}\right)$

Colony diameter $(\mathrm{mm})$

(c) $\mathrm{CaCO}_{3}$ content of watersaturated colonies (vol. $\%$ (wt \%)

Organic matter (wt \%)

Inorganic residue (wt \%)

$\begin{array}{cc}\text { Mean } & \text { Range } \\ 7.55 & 0 \cdot 0-16 \cdot 4 \\ 51 & 5-91 \\ 8 \cdot 29 & 7 \cdot 95-8 \cdot 47 \\ 2.75 & 2 \cdot 13-3.59 \\ 1.43 & 1 \cdot 16-1.78\end{array}$

Date/period

No. of 1987 measurements

$1 \cdot 16-1 \cdot 78$

$3 \cdot 42 \pm 0 \cdot 82$
$1 \cdot 25 \pm 0 \cdot 30$

$2 \cdot 17$

$0 \cdot 49-4 \cdot 25$

Aug. ' 87

354
7
14
14
14

7

14

14

7

7
50

50

$25 \cdot 6$

$48 \cdot 0$

8.2

0.73

$22 \cdot 5-27 \cdot 9$
$43 \cdot 6-51 \cdot 2$
$6 \cdot 1-9 \cdot 7$
$0 \cdot 57-1 \cdot 10$

Aug. '87

Aug. ' 87

Aug. '87

Aug. '87

10

10

10

* Time-weighted means.

Homoeothrix is marginally higher than Rivularia in this stream and is substantially higher than that for Calothrix measured at a nearby site (Pentecost, 1988a). These rates of growth indicate that, on average, only one or two new cells are produced per trichome per day. This might result from the low mean water temperature $\left(7^{\circ} \mathrm{C}\right)$. Nutrient depletion is not suspected, as bryophyte growth rates in the stream were substantial. 


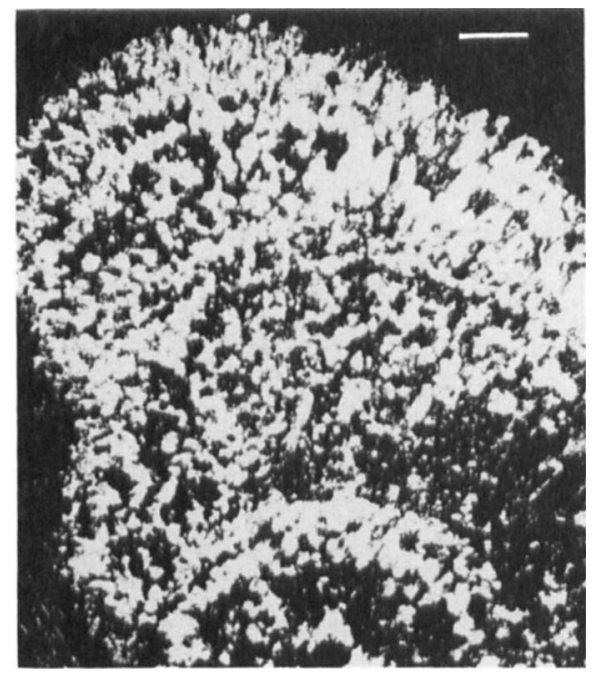

Fig. 3. Vertical section through a colony edge, viewed in cross-polarized light showing bands of microspar and micrite. Note the periodic banding in the outer calcified zone, which is $120-180 \mu \mathrm{m}$ thick, and a conspicuous double band below, probably deposited during spring. Sampled 14 August 87. Bar, $50 \mu \mathrm{m}$.

Since the colonies attained a mean diameter of $2.2 \mathrm{~mm}$ (maximum about $4 \mathrm{~mm}$ ) (Table 1), few could have survived for more than a year. This must be a consequence of the unstable habitat, characterized by high flow rates and compounded by the destructive activities of Tinodes.

The colony surface changed markedly as the season progressed. With the increase in growth during late spring, the originally farinose carbonate incrustation was replaced by a thin uncalcified network of Homoeothrix filaments. This consisted of a series of reticulate ridges 30 $60 \mu \mathrm{m}$ high and 10-50 $\mu \mathrm{m}$ wide at their apices. During September the farinose surface reappeared, with irregular crystals of calcite deposited upon and among the filaments.

All colonies examined were internally heavily encrusted with calcite although the degree of encrustation varied with the season. During May-August a pale, heavily calcified layer $0 \cdot 2-0.5$ $\mathrm{mm}$ in thickness was evident close to the colony surface (Fig. 1, rows 1-2). More detailed examination showed that this layer often consisted of a series of dense calcified bands (Fig. 3). The deposit in this layer consisted of microspar with irregular crystal faces and a tendency for the crystals to be elongated parallel to the Homoeothrix filaments. Many crystals were $50-100 \mu \mathrm{m}$ in length, often enclosing large numbers of filaments. Bands of smaller crystals, 5-20 $\mu \mathrm{m}$ in diameter, were also occasional in this zone (Fig. 3). At the colony surface, calcification was much less in evidence and the surface $60-100 \mu \mathrm{m}$ was almost free of encrustation, with occasional anhedral crystals present in the hollows between the network ridges and a thin veneer along the ridges themselves. This dense summer layer could be discerned in material collected later in the year (Fig. 1, 3rd row) and contained 39-56 vol.\% calcite. The calcification corresponded to areas with low sheath pigmentation.

During the winter, the deposits occupied $13-16 \%$ of the colony volume, indicating a less intense period of calcification. The crystals were smaller, 5-20 $\mu \mathrm{m}$ in diameter, randomly orientated and were seen enclosing filaments less frequently. Narrow bands of more intense calcification were occasionally observed in the layer deposited during this period (Fig. 1, 2nd row). The average calcium carbonate content of colonies is given in Table 1 , together with the organic matter content and the acid-insoluble residue. Homoeothrix occupied about $15 \%$ of the stream bed and precipitated approximately $100 \mathrm{~kg}$ of calcite in Waterfall Beck in the course of a year.

The formation of a dense summer band of calcite suggests a change in conditions within, or just below, the zone of active growth. During this season, deposition appears most intense in a region 70-500 $\mu \mathrm{m}$ below the surface, and in the upper part of this layer, trichomes are abundant within the sheaths. Since photosynthesis causes alkalinization of the area adjacent to the trichome, calcification may be subsequently enhanced (Pentecost, 1988b) but it is difficult to 


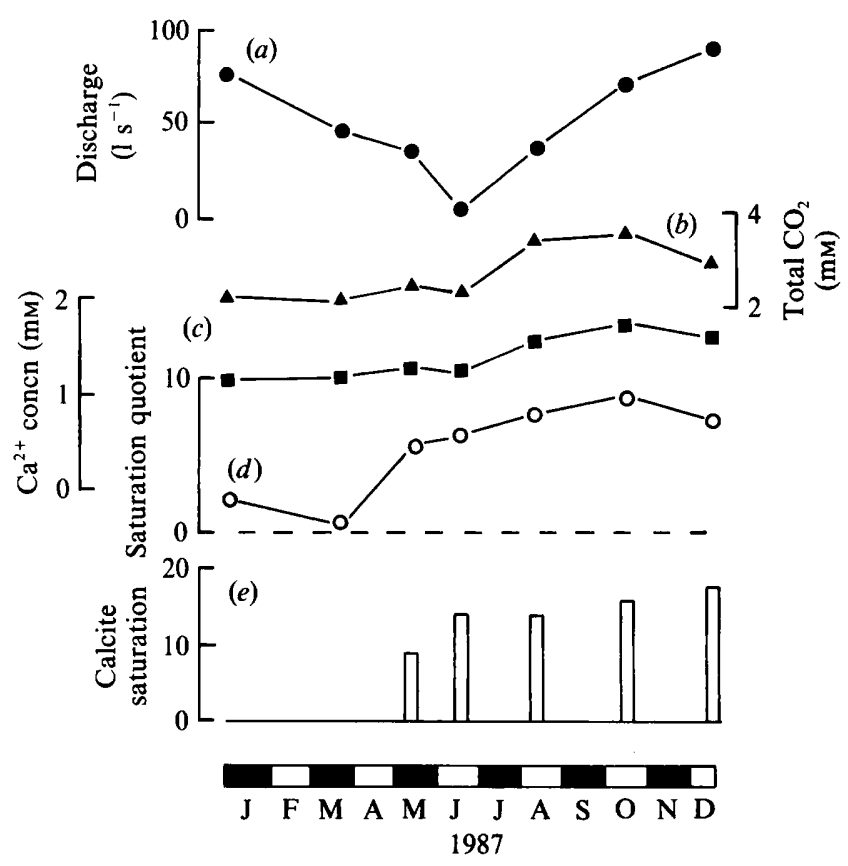

Fig. 4. (a) Waterfall Beck discharge (O). (b) Total $\mathrm{CO}_{2}(\boldsymbol{\omega})$. (c) Calcium concentration ( $\left.\mathbf{(}\right)$. (d) Calcite saturation quotient, $\Omega(O)$. (e) Calcite saturation expressed as the quantity of $\mathrm{CaCO}_{3}\left(\mathrm{mg}^{-1}\right)$ in excess of that in water at equilibrium with pure calcite at streamwater temperature (no data available for the first two samplings).

explain why the surface layer remains poorly mineralized. Because the amount of carbon fixed in these microstromatolites is small in comparison to the amount of calcite present (Table 1) it is doubtful if the amount of calcite formed is stoichiometrically equivalent to the amount of carbon dioxide fixed by photosynthesis. It is more likely that photosynthesis raises the carbonate ion activity sufficiently to nucleate calcite crystals which subsequently grow by the addition of ions diffusing into colonies from the overlying supersaturated water.

Growth and calcification of oncolites colonized by Calothrix in a nearby stream was also maximal during summer, though at a much lower rate (Pentecost, 1988a). In Rivularia, narrow bands of calcification were noted during summer and attributed in part to photosynthetic activity, whilst during winter, a dense deposit of calcite was formed abiogenially at the colony surface (Pentecost, 1987). Thus these genera, whilst closely related, show a distinctly different rate of growth and pattern of calcification.

It is tempting to attribute the banding patterns of calcification and sheath pigmentation in Homoeothrix and Rivularia to a common factor. On the basis of the available evidence, abiogenic calcification appears associated with zones of pigmented sheaths, and photosynthetically induced deposits associated with hyaline zones. This may indicate that sheath pigmentation is related to periods of slow growth.

Waterfall Beck is a permanent limestone stream with a pronounced minimum discharge during the summer (Fig. 4). The major ions present in the water were $\mathrm{Ca}^{2+}$ and $\mathrm{HCO}_{3}^{-}$. Calcium and total $\mathrm{CO}_{2}$ concentrations varied with the season, reaching a maximum in the autumn (Fig. 4). The $\mathrm{pH}$ was close to 8 at all times and the water was always supersaturated with respect to calcite at the growth-measurement site. Values of the saturation quotient, $\Omega$, ranged from 1.37 to 9.36, with the highest supersaturation in autumn and the least during winter and spring (Fig. 4). The amount of precipitable calcite ranged from 9 to $18 \mathrm{mg} \mathrm{l}^{-1}$ and tended to support the results obtained from the equilibrium calculations. 
Permission to use the facilities of Malham Tarn Field Centre by Dr K. Iball is gratefully acknowledged. This study was supported by a grant from the Central Research Fund, University of London.

\section{REFERENCES}

GeItLER, L. (1932). Cyanophyceae. In Rabenhorst's Kryptogamenflora von Deutschland, Österreich und der Schweiz, vol. 14. Edited by R. Kolkwitz. Leipzig: Akademische Verlagsgesellschaft.

KAWECKA, B. (1971). Zonal distribution of alga communities in streams of the Polish High Tatra Mountains. Acta hydrobiologica 13, 393-414.

KomÁreK, J. \& KaNN, E. (1973). Zur Taxonomie und Okologie der Gattung Homoeothrix. Archiv für Protistenkunde 115, 173-233.

KomÁreK, J. \& KovaČIK, L. (1987). Revision of several species of the genus Homoeothrix (Cyanophyta). Preslia 59, 229-242.

Mackereth, F. J. H., Heron, J. \& Talling, J. F. (1978). Water Analysis: Some Revised Methods for Limnologists. Freshwater Biological Association Scientific Publication no. 36, Ambleside, Cumbria, UK.

MARKer, A. F. H. (1976). The benthic algae of some streams in southern England. Journal of Ecology 64, 343-358.

Morisawa, M. (1968). Streams, Their Dynamics and Morphology. New York: McGraw-Hill.

Pentecost, A. (1987). Growth and calcification of the freshwater cyanobacterium Rivularia haematites. Proceedings of the Royal Society of London B232: 125-136.

Pentecost, A. (1988a). Growth and calcification of
Calothrix-dominated oncolites from northern England. In Origin, Evolution and Modern Aspects of Biomineralization in Plants and Animals. Edited by R. E. Crick. New York: Plenum (in the Press).

Pentecost, A. $(1988 b)$. Calcification processes in algae and cyanobacteria. In 4th International Symposium on Fossil Algae Edited by R. Riding. London \& New York: Academic Press (in the Press).

Pentecost, A. \& Riding, R. (1986). Calcification in cyanobacteria. In Biomineralization in Lower Plants and Animals. Edited by B. S. C. Leadbeater \& R. Riding, pp. 73-90. Oxford: Clarendon Press.

Sinclair, C. \& Whitton, B. A. (1977). Influence of nutrient deficiency on hair formation in the Rivulariaceae. British Phycological Journal 3, 297-313.

StaRmach, K. (1966a). Homoeothrix crustacea Woronichin and accompanying algae in the upper course of the River Raba. Acta hydrobiologica 8, 309-320.

STARMACH, K. (1966b). Cyanophyta-Sinice. Flora Słodkowodna Polski, vol. 2. Warsaw: Panstwowe Wydawnictwo Naukowe.

STENNER, R. D. (1969). The measurement of aggresiveness of water towards calcium carbonate. I. Transactions of the Cave Research Group 11, 175-200.

Truesdell, A. H. \& Jones, B. F. (1978). WATEQ, a computer program for calculating chemical equilibria of natural waters. Journal of Research, US Geological Survey 2, 223-248. 